Stocks, P. (1958), A.R. Brit. Emp. Cancer Campgn 1957, 35, Suppl. to Part II, p. 496.

Todd, G. F. (1966). The Reliability of Statements about Smoking Habits : Supplementary Report. Tobacco Research Council Research Paper No. 2A. London.

and Laws, J. T. (1959). The Reliability of Statements about Smoking Habits. Tobacco Manufacturers' Standing Committee Research Paper No. 2, 2nd ed. London.

Tokuhata, G. K. (1964). Amer. F. publ. Hlth, 54, 24.

T. and Lilienfeld, A. M. (1963). Publ. Hlth Rep. (Wash.), 78, 277.

U.S. Committee on Interstate and Foreign Commerce House of Representatives (1965). Cigaret Labeling and Advertising Act. U.S. Government Printing Office, Washington.
U.S. Senate Committee on Commerce (1965). Cigaret Labeling and Advertising. U.S. Government Printing Office, Washington.

U.S. Surgeon General's Advisory Committee (1964). Smoking and Health. U.S. Department of Health, Education, and Welfare, Washington.

Wicken, A. J. (1966). Tobacco Research Council Research Paper No. 9. London. In press.

and Buck, S. F. (1964). Report on a Study of Environmental Factors Associated with Lung Cancer and Bronchitis Mortality in Areas of North East England. Tobacco Research Council Research Paper No. 8. London.

Wynder, E. L., Lemon, F. R., and Mantel, N. (1965). Amer. Rev. resp. Dis., 91, 679.

\title{
Further Isolations of Reovirus Type 3 from Cases of Burkitt's Lymphoma
}

\author{
THOMAS M. BELL, $§$ B.SC., PH.D.; A. MASSIE,* $\|$ A.I.M.L.T.; M. G. R. ROSS,* B.SC. \\ D. I. H. SIMPSON, $\dagger$ M.B., B.CH., B.A.O. ; E. GRIFFIN, † F.I.M.L.T.
}

Brit. med. F., 1966, 1, 1514-1517

The attempted isolation of viruses from human tissue specimens has so far proved remarkably unrewarding. It is only from excised tonsils, adenoids, and lymph nodes that isolations have readily been obtained (Rowe et al., 1953, 1956 ; Bell and Steyn, 1962 ; McAllister et al., 1963). Viruses have also been recovered from the kidneys of children collected post mortem (BenyeshMeinick et al., 1964), from certain transplantable tumours (Moore, 1962), and from salivary glands (Smith, 1956). In every case, though it has proved possible to isolate an occasional virus from the homogenized tissue, a high recovery rate is obtained only when the tissue itself is cultured. The viruses isolated from these tissues have fallen into several groups, though the majority have been adenoviruses and herpesviruses. In addition to herpes simplex itself, varicella virus and several cytomegaloviruses have been recovered. A few strains of picornaviruses and at least one myxovirus-measles-have also been found. The remaining viruses are the $H$ strains isolated from transplantable tumours, which may be members of the papovavirus group, or belonging to the $\varnothing \times 174$ group of bacteriophages (Andrewes, 1962 ; Payne et al., 1964).

Several viruses have been demonstrated in tumour tissue excised from cases of Burkitt's lymphoma (Burkitt, 1962). From cases collected in Uganda six strains of herpes simplex have been isolated (Woodall et al., 1965 ; Simons and Ross, 1965), while a herpes-like virus has been demonstrated by electron microscopy in cultures of the tumour cells (Epstein et al., 1964 ; Stewart et al., 1965) and in direct biopsy material (Allbrook et al., 1966). Six agents, as yet unidentified, have been isolated from cases in Kenya (Dalldorf and Bergamini, 1964). The isolation of a single reovirus has already been reported by this group (Bell et al., 1964), and the present paper deals with the identification of this virus and its isolation from another eight cases in Uganda.

\section{Methods and Materials}

Between November 1963 and December 1964 tumour biopsy specimens were collected from 24 cases of Burkitt's lymphoma at Mulago Hospital, Kampala ; from two cases at the Freda

- Imperial Cancer Research Fund, P.O. Box 193, Entebbe, Uganda. † East African Virus Research Institute, P.O. Box 49, Eniebbe, Uganda. \# Department

Leverhulme Trust Research Fellow.

if Leverhulme Trust Research Associate.
Carr Hospital, Ngora, Uganda ; and from five cases at the Regional Hospital, Mwanza, Tanzania. Maitland-type cultures of all biopsies were set up in 6-cm. plastic Petri dishes with media $A, C$, and $L$. In some cases explant cultures were prepared in stationary tubes with a fowl plasma clot fed with medium C (Bell and Steyn, 1962). Sheets of fibroblasts which grow from these cultures were passaged, $0.25 \%$ trypsin (Difco $1: 250)$ being used. Media A and C consisted of Hanks's BSS plus $2 \%$ (A) or $20 \%$ (C) calf serum and $0.5 \%$ LAH. Medium $\mathrm{L}$ was prepared from Eagle's $\mathrm{MEM}$ plus $0.2 \% \mathrm{NaHCO}_{3}$ and $0.03 \%$ glutamine.

The suspensions of lymphoblasts which grew out from the biopsies were inoculated into tube or plate cultures of human embryo kidney (H.E.K.), human embryo lung (H.E.Lu.), Grivet monkey kidney (M.K.), or hamster kidney (Ham. K.) cells. Similarly, culture fluids from the fibroblast and explant culture were inoculated in aliquots of $0.2 \mathrm{ml}$. per tube and $0.5 \mathrm{ml}$. per plate. Finally, tissue fragments from each tumour were inoculated direct into cultures of M.K. or H.E.K. cells. Most inoculated cultures were maintained in medium L. Control cultures were maintained from each batch of cells until natural degeneration occurred. Specific degeneration did not occur in any control cultures, only end-of-life degeneration.

Antiserum was prepared in rabbits against the CAN 230 strain as described previously for E.C.H.O. viruses (Bell, 1962). Neutralization tests were carried out by mixing $0.25-\mathrm{ml}$. aliquots of serial twofold dilutions of serum with $0.25 \mathrm{ml}$. of virus dilution in medium $A$ to give a final concentration of 100 $\mathrm{TCD}_{50}$ of virus per $0.2 \mathrm{ml}$. of mixture. The serum and virus were incubated for one hour at $34^{\circ} \mathrm{C}$. before inoculating 0.2 $\mathrm{ml}$. into two tubes of M.K. cells.

The prototype strains of reovirus types 1,2 , and 3 were kindly supplied by Dr. A. D. Macrae, Central Public Health Laboratory, Colindale, England.

Material was prepared for examination in the electron microscope as follows. Confluent monolayers of M.K. cells in 10-cm. Petri dishes were infected with the prototype strain of reovirus type 3 or two of the isolated strains-CAN 228/2 or CAN 230. When $50 \%$ of the cells showed a cytopathic effect the monolayer was removed with $0.25 \%$ trypsin and the resulting cell suspension was fixed in $5 \%$ gluteraldehyde and post-fixed in Palade's buffered osmic acid before spinning down to form a solid pellet. The pellet was embedded in Araldite after dehydration, sectioned, stained in uranyl acetate in $50 \%$ alcohol, and examined in a Zeiss EM9 electron microscope. 


\section{Results}

A total of 12 strains were isolated from nine cases of Burkitt's lymphoma. One of these (CAN 309) produced the typical appearance of herpes simplex in tissue culture, while the remaining 11 gave the cytopathic effect characteristic of reovirus. Details of the patients from whom virus was isolated are given became sick between post-inoculation days 6 and 12, dying between days 8 and 14. Further mouse passage reduced the average survival time to 7 to 10 days. All the tissue-culture viruses tested were pathogenic for mice, except strain CAN 220, where no illness was produced.

Electron micrographs of the prototype and the CAN 230 strains of reovirus type 3 are shown in Figs. 1 and 2 . The

TABLE I.-Viruses Isolated from Lymphoma Cases

\begin{tabular}{|c|c|c|c|c|c|c|c|c|}
\hline $\begin{array}{l}\text { Burkitt } \\
\text { No. }\end{array}$ & $\begin{array}{l}\text { I.C.R.F. } \\
\text { No. CAN }\end{array}$ & $\begin{array}{l}\text { Age } \\
\text { Se }\end{array}$ & and & Tumour & $\begin{array}{l}\text { Method } \\
\text { of Isolation }\end{array}$ & $\begin{array}{c}\text { Infectivity } \\
\text { Titre* }\end{array}$ & $\begin{array}{c}\text { Titre of Can } 230 \\
\text { Serum Against Virust }\end{array}$ & $\begin{array}{l}\text { Identity of } \\
\text { Virus }\end{array}$ \\
\hline $\begin{array}{l}\mathrm{J} 214 \\
\mathrm{~J} 225 \\
\mathrm{~J} 226 \\
\mathrm{~J} 227 \\
\mathrm{~J} 241 \\
\mathrm{~J} 248 \\
\mathrm{~J} 249 \\
\mathrm{~K} 131 \\
\mathrm{~K} 194\end{array}$ & $\begin{array}{l}222 / 2 \\
222 / 4 \mathrm{a} \\
222 / 4 \mathrm{~b} \\
224 \\
228 / 2 \\
228 / 5 \\
230 \\
287 \\
309 \\
306 \\
220 \\
246\end{array}$ & $\begin{array}{r}9 \\
4 \\
4 \\
5 \\
4 \\
6 \\
7 \\
16 \\
21\end{array}$ & $\begin{array}{l}\mathbf{F} \\
M \\
\mathrm{~F} \\
\mathrm{M} \\
\mathrm{M} \\
\mathrm{M} \\
\mathrm{M} \\
\mathrm{F} \\
\mathrm{M}\end{array}$ & $\begin{array}{l}\text { R. upper eyelid } \\
\text { R. max./mand. } \\
\text { L. ", } \\
\text { L. cheek } \\
\text { R. maxilla } \\
\text { R. max./mand. L. max. } \\
\text { R. mandible } \\
\text { Bilateral ovaries } \\
\text { L. lumbar }\end{array}$ & $\begin{array}{l}\text { Explant culture } \\
\text { 3rd pass. fibroblasts } \\
\text { Explant culture } \\
\text { 3rd pass. lymphoblasts } \\
\text { 3rd pass. lymphoblasts } \\
\text { 1st "” "” } \\
\text { M̈inced tissue" } \\
\text { Tissue fragments } \\
\text { 4th pass. lymphoblasts } \\
\text { 1st ", " }\end{array}$ & $\begin{array}{l}5 \cdot 5 \\
5 \cdot 0 \\
4 \cdot 0 \\
5 \cdot 5 \\
7.0 \\
4 \cdot 0 \\
7 \cdot 0 \\
6 \cdot 0 \\
3 \cdot 5 \\
5 \cdot 0 \\
5 \cdot 5\end{array}$ & $\begin{array}{l}80 \\
60 \\
80 \\
60 \\
40 \\
20 \\
40 \\
30 \\
30 \\
10 \\
80\end{array}$ & $\begin{array}{c}\text { Reo } 3 \\
\text { M } 3 \\
\text { Reo } 3 \\
\text { " } 3 \\
3 \\
\text { Probably herpes } \\
\text { Reo } 3 \\
\text { Probably not Reo } 3 \\
\text { Reo } 3\end{array}$ \\
\hline
\end{tabular}

*Expressed as the negative of TCDso.

† Expressed as a reciprocal.

in Table I. With the exception of CAN 309, which was isolated direct from minced tissue, the details of each strain of virus are given in Table I.

The infectivity titres of the viruses given in Table I are for stocks of virus after passage in M.K. cells, irrespective of the cells in which the virus was initially isolated. It was this stock virus which was used for the neutralization tests. All titrations and neutralization tests were carried out in M.K. cells. All strains of virus grow in H.E.K. and M.K. cells, and all those tested grow in Ham. K. and H.E.Lu.

In all cross-neutralization tests between CAN 230 and reovirus types 1 and 2 there has been no evidence of neutralization at the lowest dilution tested $(1: 10)$.

The strain CAN 220 was not neutralized by the CAN 230 antiserum, and has not yet been identified. The remaining strains were neutralized and appear to be closely related to, if not identical with, CAN 230.

Three isolations were made from Case J214 (previously described by Epstein and Barr, 1965). Two separate pieces of biopsy material were cultured-one from the centre of the tumour and one from the periphery. The virus was recovered in one experiment from the former, CAN 222/2, and in two experiments from the latter, CAN 222/4a and CAN 222/4b. Finally, Case J226 was biopsied twice-first on 24 December 1963 , when tumour tissue was taken, and again on 14 January 1964, when a normal right inguinal lymph node was excised. Virus was isolated from both specimens-CAN 228/2 and CAN 228/5.

Cross-neutralization tests were carried out between the prototype strain of reo 3 and the CAN 230 strain by means of monkey antiserum against reo 3 , kindly supplied by Dr. M. $H$. Hambling, and rabbit antiserum prepared against CAN 230. These results are given in Table II.

TABLE II.-Cross-neutralization of CAN 230 and Reo 3

\begin{tabular}{|c|c|c|c|c|}
\hline \multirow{2}{*}{\multicolumn{3}{|c|}{ Virus }} & \multicolumn{2}{|c|}{ Serum Neutralization Titres* } \\
\hline & & & \multirow{2}{*}{$\begin{array}{c}\text { Reovirus } 3 \\
200 \\
1,600\end{array}$} & \multirow{2}{*}{ 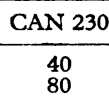 } \\
\hline $\begin{array}{l}\text { CAN } 230 \\
\operatorname{Reo}^{2} \text {.. }\end{array}$ & $\ldots$ & $\ldots$ & & \\
\hline
\end{tabular}

No agent was isolated when $10 \%$ suspensions of biopsy material, in $0.75 \%$ bovine plasma albumin (Armour fraction V) in a phosphate buffer of $\mathrm{pH} 7.4$, were inoculated into newborn mice intracerebrally, intraperitoneally, and subcutaneously. Tissue-culture virus, however, when inoculated intracerebrally into newborn mice produced sickness, runting, and an "oilycoat" appearance. Paralysis followed later. When adapted to mice the virus titred between $10^{-5.2}$ and $10^{-6.8} \mathrm{LD}_{50} / \mathrm{ml}$. Mice dimensions found for the three strains from our micrographs are given in Table III, which also includes the recognized figures for this group of viruses (Vasquez and Tournier, 1962).

\begin{tabular}{|c|c|c|c|}
\hline & & Overall Size & Internal Core \\
\hline $\begin{array}{l}\text { Reovirus } \\
\text { Reo } 3 \\
\text { CAN } 230 \\
\text { CAN } 228\end{array}$ & $\begin{array}{l}\because \\
\because \\
\cdots\end{array}$ & $\begin{array}{l}595 \AA( \pm 25 \AA) * \\
612 \AA( \pm 25 \AA) \\
619 \AA( \pm 62 \AA) \\
565 \AA( \pm 15 \AA)\end{array}$ & $\begin{array}{l}325 \AA( \pm 15 \AA) \\
306 \AA( \pm 37 \AA) \\
340 \AA( \pm 31 \AA) \\
315 \AA( \pm 15 \AA)\end{array}$ \\
\hline
\end{tabular}

\section{Discussion}

Related strains of virus have been isolated from the tumour tissue of seven cases of Burkitt's lymphoma. In one case an isolation was also made from a normal lymph node excised three weeks after the original tumour biopsy, when the tumour was regressing under chemotherapy. All but two of the isolations were made only in cells maintained in serum-free medium. All strains produced the illness in mice characteristic of reovirus type 3 and are neutralized by antiserum against one strain, CAN 230. A certain degree of antigenic heterogeneity is apparent when compared with the prototype strain of reo 3, but this is very common within the reovirus group (Bell, 1965). These 10 strains of virus can therefore be classified as reovirus type 3.

Only six of the seven cases came from Mulago Hospital, while the seventh was from Ngora. This indicates that reovirus type 3 is associated with at least a proportion of the cases of Burkitt's lymphoma and has not been picked up as a hospital infection. In view of the negative results obtained by Girardi et al. (1962), using similar methods on a variety of human tumours, the significance of these findings must be considered.

Burkitt's lymphoma was originally believed to occur only in that part of Africa bounded by the parameters-mean monthly temperature never less than $60^{\circ} \mathrm{F} .\left(15^{\circ} \mathrm{C}\right.$.) and/or an annual rainfall of not less than $20 \mathrm{in}$. $(50 \mathrm{~cm}$.) (Haddow, 1963). This observation led Davies to put forward the hypothesis that an arthropod-borne virus might play a part in the causation of the tumour (Burkitt, 1962). It is also known that there is a high incidence in New Guinea, which has a climate similar to that of tropical Africa (ten Seldam et al., 1966). However, cases have been identified in the U.S.A. and England (O'Conor et al., 1965 ; Dorfman, 1965 ; Wright, 1965). These areas are well outside the originally defined parameters, and, in the case of England, completely outside the known areas of distribution of any arthropod-borne virus.

Haddow (1964) stated that there was nothing in the age distribution of cases to conflict with the view that an arbovirus 
could be the causative agent. Though the greatest incidence of Burkitt's lymphoma is in children, occasional cases do occur in adults. Recent analysis of the adult cases in Uganda has shown that they have occurred mainly in immigrants from areas which are free of the disease-that is, Kigezi District and the Republic of Ruanda. Both these areas fall outside the climatically defined lymphoma belt (Burkitt and Wright, 1966). Not only does this not conflict with the hypothesis of an arthropod-borne virus as the cause but rather it tends to strengthen this view. Discussing the aetiology of Central African lymphomata, Harris (1964) concludes " that the tumour probably results from a bizarre host reaction towards a common arthropod-borne virus or group of viruses," though he does not exclude the possibility of the intervention of chemical carcinogens.

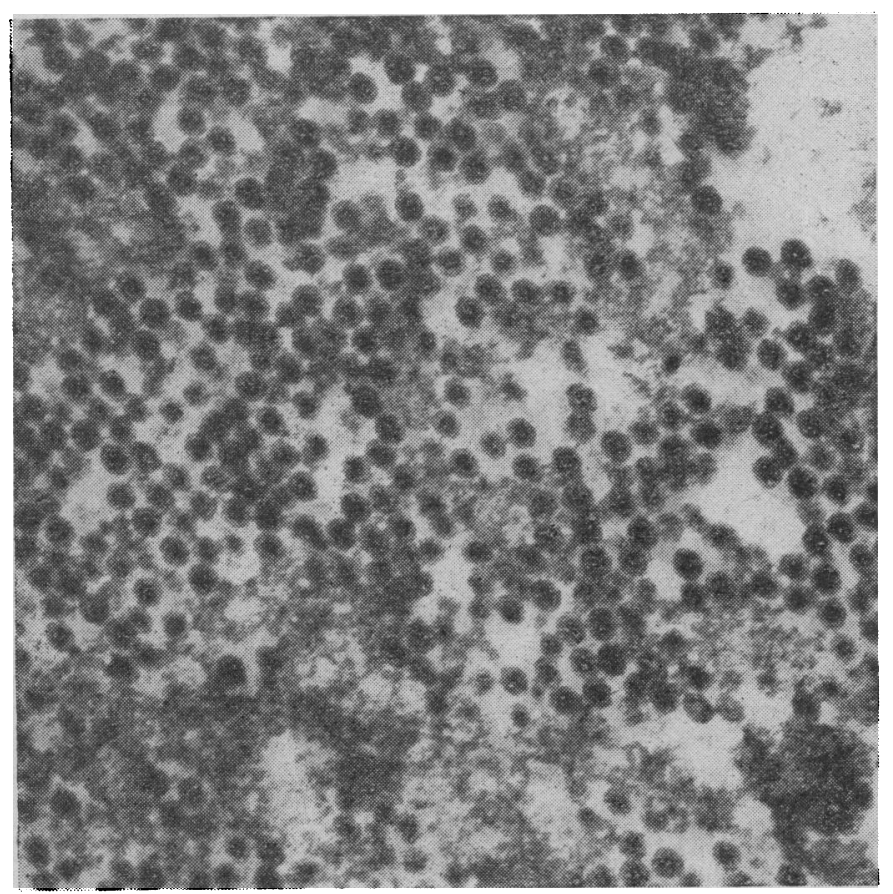

FIG. 1.-Prototype strain of reovirus type 3. $(\times 47,600$.

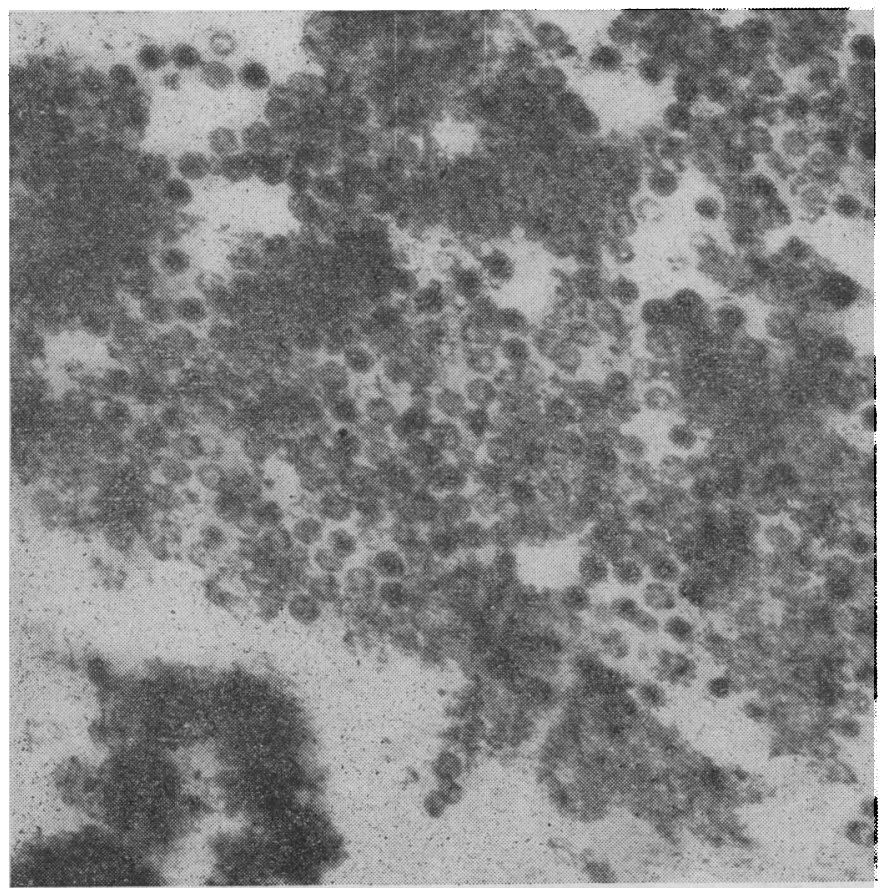

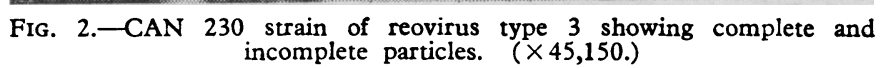

If we take into account the American and British cases it becomes necessary to reconsider the original hypothesis. It is possible that there is no specific virus aetiology of Burkitt's lymphoma, but that it is a bizarre reaction to a wide range of viruses. Alternatively, if one assumes that there is a specific aetiology, then this virus or group of related viruses must be capable of transmission in some other way than by an insect vector. The hypothesis therefore becomes: The aetiological agent of Burkitt's lymphoma is a virus which is arthropodvectored under suitable climatic conditions but which may be transmitted in other ways.

It is possible to draw certain other conclusions regarding the properties of this postulated virus. From the incidence of the tumour it would appear that it is much more common in tropical than in non-tropical areas. Alternatively, if the incidence is the same then the arthropod transmission must alter the effects of the virus. One such effect could be the induction of a viraemia, which is likely to occur when the virus is directly injected by an insect bite, but which may not occur if the initial infection takes place through the respiratory or alimentary tracts. It would also seem probable that it has an alternative host or hosts, possibly ones in which a viraemia regularly occurs.

The properties of the reoviruses fall fairly well into this range. They have not yet been shown to cause serious disease in any animal species, though they have a very wide host range. A viraemia is known to occur in mice but it has not yet been reported in man. At least one, type 3, can be transmitted by mosquitoes, although this is not usually the case. It must also be remembered that certain plant reoviruses, one of which, wound tumour virus, causes tumours, are arthropod-vectored (Bell, 1965 ; Parker et al., 1965). Stanley (personal communication) has recently obtained a murine lymphoma after inoculation of mice with reovirus type 3 .

Members of the herpesvirus group have also been demonstrated frequently (Epstein et al., 1964 ; Woodall et al., 1965 ; Simons and Ross, 1965 ; Stewart et al., 1965 ; Allbrook et al., 1966) in biopsies of tumour tissue. It is therefore possible that latent infections with these viruses may also play a part in the aetiology of Burkitt's lymphoma. One member of this groupthe Lucké frog-kidney tumour virus-is associated with tumour formation (Lunger, 1964), but there is no evidence that any member can be arthropod-vectored.

It has already been noted that reovirus 3 was isolated from one of the cases shown to be carrying a herpesvirus-Case J214-while particles similar to this herpesvirus have been seen in the reovirus-associated murine lymphoma (Stanley, personal communication). There are, at present, insufficient data to decide whether the herpes-like D.N.A. virus of Epstein or this R.N.A. reovirus is the aetiological agent for the Burkitt lymphoma. It is possible that neither is involved, and equally possible that the tumour is the result of some interaction in cells between both these viruses, with the intervention of other environmental factors.

We now have evidence (Bell and Ross, 1966) that reovirus 3 can give a latent infection in human embryonic cells which persists while the cells are actively dividing. There is no shortage, therefore, of working hypotheses.

In particular, serological studies must be continued. We are at present extending the survey of both lymphoma and control sera, the preliminary results of which have been recorded (Bell et al., 1964) and which continue to show a higher incidence of antibody to reovirus type 3 in the lymphoma sera than in the controls.

\section{Summary}

Twelve strains of virus have been isolated from nine cases of Burkitt's lymphoma. Ten of these, from seven cases, are 
reovirus type 3. One of the others appears to be herpes simplex, while the twelfth has not yet been identified. The appearance of these reovirus strains in the electron microscope and their effects on mice were characteristic, and it is concluded that reovirus is associated with at least a proportion of the cases of Burkitt's lymphoma. The implications of these findings are discussed in the light of new epidemiological evidence.

We wish to thank Dr. G. F. Marrian, Director, Imperial Cancer Research Fund; Dr. R. J. C. Harris, Head of Division of Experimental Biology and Virology; the Director, E.A. Virus Research Institute ; and Professor D. B. Allbrook, Anatomy Department, Makerere University College, for their help and encouragement throughout the survey. We are grateful to Mr. D. P. Burkitt and Mr. S. Kyalwazi, Department of Surgery, Makerere University College ; Mr. C. Patel, Regional Medical Officer, Mwanza, and Dr. J. Maitland, Freda Carr Hospital, Ngora, for the supply of tumour tissue; and to Professor M. S. R. Hutt and Dr. D. H. Wright, Pathology Department, Makerere University College, for histological confirmation. We appreciate the supply of serum specimens from Mr. P. P. Clifford, Kenyatta National Hospital, Nairobi ; of human embryonic tissue from Dr. H. E. M. Kay, Royal Marsden Hospital, London; and of monkeys from Mr. T. Mann, Entebbe.

This work was supported in part by a grant from the Leverhulme Trust. The electron-microscopical work was done in the Wellcome Electron Microscope Laboratory, and the expenses were defrayed by a grant from the Tropical Medical Research Board of the Medical Research Council.

\section{REFERENCES}

Allbrook, D. B., Wright, D. H., and Griffin, E. R. (1966). To be published.

Andrewes, C. H. (1962). Advances in Virus Research, vol. 9, edited by K. M. Smith and M. A. Lauffer. Academic Press, New York and London.

Bell, T. M. (1962). Scot. med. 7., 7, 85.
(1965). An Introduction to General Virology, chapt. 12, p. 95. Heinemann, London.

- Massie, A., Ross, M. G. R., and Williams, M. C. (1964). Brit. med. 7., 1, 1212 .

and Ross, M. G. R. (1966). In press.

— and Steyn, J. H. (1962). Brit. med. F., 2, 700.

Benyesh-Melnick, M., Rosenberg, H. S., and Watson, B. (1964). Proc. Soc. exp. Biol. (N.Y.), 117, 452 .

Burkitt, D. P. (1962). Postgrad. med. 7., 38, 71.

- and Wright, D. H. (1966). To be published.

Dalldorf, G., and Bergamini, F. (1964). Proc. nat. Acad. Sci. (Wash.), $51,263$.

Dorfman, R. F. (1965). Cancer, 18, 418.

Epstein, M. A., Achong, B. G., and Barr, Y. M. (1964). Lancet, 1, 702.

- and Barr, Y. M. (1965). 7. nat. Cancer Inst., 34, 231.

Girardi, A. J., Slotnick, V. B., and Hilleman, M. R. (1962). Proc. Soc. exp. Biol. (N.Y.), 110, 776.

Haddow, A. J. (1963). E. Afr. med. F., 40, 429.

- (1964). Ibid., 41, 1.

Harris, R. J. C. (1964). Brit. med. Bull., 20, 149.

Lunger, P. D. (1964). Virology, 24, 138.

McAllister, R. M., Mikenas, M., Straw, R. M., and Landing, B. H. (1963). Lab. Invest., 12, 342.

Moore, A. E. (1962). Virology, 18, 182.

O’Conor, G. T., Rappaport, H., and Smith, E. B. (1965). Cancer, 18, 411.

Parker, L., Baker, E., and Stanley, N. F. (1965). Aust. F. exp. Biol. med. Sci., 43, 167.

Payne, F. E., Beals, T. F., and Preston, R. E. (1964). Virology, 23, 109.

Rowe, W. P., Hartley, J. W., Waterman, S. Turner, H. C., and Huebner, R. J. (1956). Proc. Soc. exp. Biol. (N.Y.), 92, 418.

Huebner, R. J., Gilmore, L. K., Parrott, R. H., and Ward, T. G. (1953). Ibid., 84, 570 .

Simons, P. J., and Ross, M. G. R. (1965). Europ. F. Cancer, 1, 135.

Smith, M. G. (1956). Proc. Soc. exp. Biol. (N.Y.), 92, 424.

Stewart, S. E., Lovelace, E., Whang, J. J., and Ngu, V. A. (1965). 7. nat. Cancer Inst., 34, 319.

ten Seldam, R. E. J., Cooke, R. A., and Atkinson, L. (1966). Cancer, $19,437$.

Vasquez, C., and Tournier, P. (1962). Virology, 17, 503.

Woodall, J. P., Williams, M. C., Simpson, D. I. H., and Haddow, A. J. (1965). Europ. 7. Cancer, 1, 137.

Wright, D. H. (1965). Israel f. med. Sci., 1, 177.

\title{
Gastro-duodenal Mucosal Prolapse After Billroth I Gastrectomy
}

\author{
G. P. G. SIM,* M.B., CH.B., F.F.R., D.M.R.D., M.C.R.A.
}

[With Special Plate]

Brit. med. F., 1966, 1, 1517-1518

Prolapse of mucosa through the orifices of the stomach is of recurrent interest, but the particular complication of mucosal prolapse after Billroth I partial gastrectomy has received little notice. This paper refers to three cases of gastro-duodenal mucosal prolapse diagnosed in a period of eight months by barium-meal examination. Each patient had previously undergone gastrectomy of the Billroth I type, and one subsequently underwent further surgery at which prolapse was confirmed and resected.

\section{Case 1}

A man aged 45 had a history of dyspepsia dating back to 1952 . An ulcer had been seen on the lesser curve of the stomach at gastroscopy in October 1961, and a Billroth I partial gastrectomy was performed in August 1962. In July 1964 he complained of nausea of two months' duration, especially in the morning, together with a constant ache in the mid-abdomen and left loin. There was no history of intestinal bleeding. His haemoglobin was $14.0 \mathrm{~g} . /$

* $X$-ray Department, Wellington Hospital, Wellington, New Zealand.
$100 \mathrm{ml}$. Barium-meal examination showed changes in the gastroduodenal junction consistent with prolapse of gastric mucosa (Special Plate, Fig. 1) but no other abnormality.

His subsequent history includes further intermittent bouts of abdominal pain.

\section{Case 2}

A woman of 58 had a haematemesis in September 1949, when a barium-meal examination showed a duodenal ulcer. A further haematemesis occurred in September 1960. In November of the same year a Billroth I type partial gastrectomy was carried out with removal of more than two-thirds of the stomach. In August 1964 she was admitted to hospital because of two melaena stools in three days and abdominal pain for two weeks. This pain, sometimes severe, was epigastric in situation and occurred before and after meals. Faeces were strongly positive for occult blood. The haemoglobin level was $10.5 \mathrm{~g} . / 100 \mathrm{ml}$. A barium-meal report stated: "A smooth, roughly hemispherical filling defect protrudes into the commencement of the duodenum from the region of the anastomosis. This appearance is consistent with prolapse of the gastric mucosa" (Special Plate, Fig. 2). 